\title{
Marriage is a Mirage
}

Dr. Hemanth Kumar Mekathoti

Assistant Professor in English

Malla Reddy Engineering College (A)

Hyderabad, India

hemanthmekathoti@gmail.com

Dr. Narasinga Rao Barnikana

Asst. Prof. of English (NPIU/TEQIP)

Department of Humanities

Samrat Ashok Technological Institute

Vidisha, Madhya Pradesh-464001, India

b.nani7777@gmail.com

Abstract

Indian female writers attempt to depict the problems of women in the modern society dominated by male chauvinism and in rural India in particular, touching the feministic sensibilities. These female writers handle astonishing variety of themes. Among the women modern writers of fiction Kavery Nambisan occupies a unique place for more than one reason.She has begun her literary career by writing numerous children's books. Female characters in her novels truly feel that love and marriage are not mere accidents but it is a trap and a cage where emotional stress haunts them through lack of care, bondage and love.

The character 'Shari' of Kavery Nambisan's second novel Mango-Coloured Fish (2000), is a young girl, who is caught in a complex, entanglement of uncertainties and 
disillusionments, and she has different notions about the institution of marriage. Nambisan successfully depicted the contemporary younger generation pre and past marriage dilemmas and ordeals effectively and lively. The protagonist Shari wants to trace out her self-identity and freedom in this world and this is clearly presented in the novel Mango-Coloured Fish.

Keywords: Women, traditions, patriarchal customs, human relations, gender discrimination, marriage, self- identity, freedom.

Indian female writers attempt to depict the problems of women in the modern society dominated by male chauvinism and in rural India in particular, touching the feministic sensibilities. These female writers handle astonishing variety of themes. Their novels include various concepts of facts and fiction and are based on contemporary events and social problems. These women novelists, who have high educational and intellectual standards, have sharpened their observation of life and have imparted a psychological depth to their writings. So these writers have created a new canvas for the younger generation of Indian women novelists. Among the women modern writers of fiction Kavery Nambisan occupies a unique place for more than one reason. Though she is a surgeon by profession, she has become a writer by choice and temperament.

Kavery Nambisan has begun her literary career by writing numerous children's books. Female characters in her novels truly feel that love and marriage are not mere accidents but it is a trap and a cage where emotional stress haunts them through lack of care, bondage and love. Kavery Nambisan through the character Shari in her second novel Mango-Coloured Fish(2000) portrays the Indian traditional family and the patriarchal customs. Shari respects her parents and obeys their words and accepts to get married. Later she breaks her engagement with Gautam and wraps her engagement ring in hand-kerchief which resembles that the modern women intend to be self- reliant and to live their own life. 
Parental impact on the growth of women

The story of the novel deals with human relations in a close-knit, Tamil Chettiar's family from Madras is staying in Delhi. The family consists of father, mother Ahalya (nickname Bimmy) and they have a son named Krishna, who has excelled his job as an Assistant Professor of Surgery at Stanley Medical and is married to Tejaswini, an anaesthetist. Chitra, Shari's elder sister married a person having M.B.A. degree, who is working in Lucknow and the protagonist, Sharada as 'Shari' who is twenty two years old. Shari's father is the Managing Director of a garment export firm. He is very vigorous and assertive in his office transactions but his status in the family is apart from it and he is putty in his wife's hands. The export business for which Shari's father worked opened a branch in Madras and he is transferred to Madras Branch. It was since fourteen years, the family lives there, and the protagonist is eight years old when they started living there.

Her father appears as an encyclopaedia of superficial knowledge to Shari. To Shari her mother is a different type of creature who has extravagant pride of superiority of Delhi culture and is ashamed of being a Tamilian. She immensely converted her father's identity of Tamilian into Delhian. When her Parents arrange her marriage with a successful software engineer Gautam and discuss the gifts (Dowry) to be exchanged; she feels very awkward and embarrassed about the dowry but fails to raise her voice as she is conditioned to remain passive. She doesn't open up her feelings any time, things just happen to her. Her mother and sister are larger than life and loom large trying to lay control over everything - from the dresses to tresses, from marriage to honeymoon

Subsequently, Shari's marriage is finally fixed with young Gautam, to whom Chitra and Mother favoured from the point of views as money gifted, intelligent and sense of humour. But Shari became overwhelmed by exaggerated fears of awkwardness to this relationship. Women pay for their happiness at the cost of their freedom. In this context De 
Beauvoir emphasizes that such a sacrifice on the part of a woman is too high for anyone because the kind of self-contentment, serenity and security that marriage offers woman drains her soul of its capacity for greatness.

Relationship between a mother and daughter

According to Indian novelist Shashi Deshpande, mother-daughter relationship is considered to be one of the most emotional as well as psychological bonding between two women. This bond seems to be a source of energy for women or for a girl child because they both can empathise with each other : "For any daughter, the relationship with her mother is the first relationship in her life, and may also be the most important she will ever have" (Hammer 1). Thus, they psychologically unite with Centre. However the fundamental problem arises when a mother, who herself is a patriarchal construct, tries to impose her patriarchal principles and values on her daughter.

During Shari's childhood days on one occasion, her family was travelling to Mahabs for picnic, Shari puked over her purple taffeta dress and she felt sick of it. On this occasion, Mother sprang away as if she had been struck and screamed father to stop the car. She got out and instead of washing Shari's dress; she inspected the folds of her crisp blue Chikan sari for stains. On the contrary, aunt Paru extricated Shari from the purple taffeta mess and washed her even uncle poured the water to clean her. And later aunty took her on her lap but her Mother's role to Shari is neutral.

A feminist sociologist and psychoanalyst Nancy Chodorow, in her book The Reproduction of Mothering: Psychoanalysis and the society of Gender(1978), argues that the mother-infant relationship is asymmetrical in its mutuality as the infant's need for the mother is absolute while the mother's is relative. 
There is no evidence; she goes on to add, to suggest that exclusive mothering is necessarily better for infants. However, such mothering is good for society as it may produce more achievement-oriented individuals with psychologically monogamist denies. (Chodorow81)

Thus, in psychoanalytic theory, if one measures a mother's goodness or badness is whether the mother and child's interests are identical.

\section{Gender discrimination}

The consciousness of gender in Nambisan's characters focuses the reader's attention on a key force of oppression in the contemporary world and the consequent division of the world into a "man's world" and a "woman's world". She engages the issues and works through them to reveal that woman like man, is a gift to the world. The gender inequality followed by the society from times immemorial has made the confused construct of a woman through conventions which ultimately has led to this sorry picture of inhibited individuality of a woman and any attempt from her side to exhibit her independence is considered as weakness in character.

Indeed, the protagonist Shari also becomes aware of how gender discrimination is practiced in her family that she is not much loved by her mother when compare to her brother Krishna. This discriminating attitude is familiar in the West which is claimed to be much advanced nation technologically. Even in Doris Lessing's Martha Quest (1952), while her younger brother Jonathan with "half her brains" is put in an "expensive school, like a visitor from a more prosperous world", (MQ 34) she is studying in a local school. The awareness of the biased attitude makes her self-reliant, and defiant towards her parents, and she decides to seek her own identity outside the parental hold. 


\section{Importance of marriage}

Marriage is one of the most important institutions of human society. It has been variously defined by sociologists as well as by legal luminaries. Marriage in a traditional society is a continual self-sacrifice for a woman, a denial of even her selfhood as a person. Whatever she does, she actually does for her husband to please him as her master. Women in the novels of Kavery Nambisan truly feels that love and marriage are not mere accidents but it is a trap and a cage where emotional stress haunts them through lack of care, bondage and love, this can be compared to character Indu, who says in Deshpande's Roots and Shadows (1992): It's a trap ... that's what marriage is. (RS 74)

In the life of an Indian woman all exist against the certainty of marriage and it marks a point of maturing that signifies the flowering of life. In Indian society a traditional marriage cannot take place, if the caste of both man and woman is not the same.

Pre and post marriage issues

Nambisan successfully depicted the contemporary younger generation pre and past marriage dilemmas and ordeals effectively and lively.Shari also ponders that her parents do not appear to enjoy being married to each other. She never sees them teasing each other or they never sat closely together and even she could not imagine them touching. Krishna and Shari considers that their parent's marriage though peaceful yet lacked love but in the case of aunt Paru and uncle, she witnesses what love did to the two of them. The word 'marriage' to Shari appears so slippery that sometimes she reacted very negatively. When their maid servant Ruku's marriage was called off on account of demanding excessive dowry from the side of groom, Shari comforts her by saying about it and also askes her: 
And what do you want a husband for? Where does it say that a girl must marry? If you have education, you can get a better job than this, earn more.

Like most of the protagonists of the contemporary Indian novels, Shari too is confronting isolation or loneliness in her life. Shari has always felt lonely amidst the stifling of her sophisticated mother, a passive sister and a submissive father. The emotional distance has always been compelling and grueling. Just before her marriage with a successful software engineer; she undertakes a journey to meet her brother and her childhood friends to find answers to her many questions on the multi-layered meaning of marriage. Her journey, though physical on the outer surface is, in fact, a plunge into her heart and into her emotional psyche. She drifts into her past and tries to rediscover herself by resurrecting the long forgotten memories and finally resurfaces as a woman with a new found freedom and a better understanding about marriage. Meanwhile the shocking result of Shari's market survey on marriage prompts her to be on her own for a while. Now she has decided to cancel her return to Madras and she wishes to find a part-time job and to stay into a hostel as she wants to 'sort out something'. Like a sudden revelation, she strongly and urgently wants to be on her own for a while.

Quest for identity

Kavery Nambisan as a third generation novelist is a writer whose meaningful works are from the perspective of women's identity and liberation. She depicts the inner segregated state of women in the Indian context. Her works focus on the women oriented issues and she determines for a social change and change in the inner conscious of women by focusing on their self also. She even aspired for emancipation of self of women and had an extreme quest in her works for identity crisis of women. She has to her credit four novels in which quest for 
self is a predominant theme. In the present novel Shari's predicament of marriage and search for identity is portrayed. Nambisan also presented other young generation characters like Krishna, Teji, Yash, Chitra, hostel warden George and his beloved Portia.

Shari wants to redefine her self-identity and desires to visualize self-discovery by visiting remote places of her dearest ones and try to perceive her with the concept of marriage as an institution even before entering into it. Shari herself reviews her personality in her own words as:

And physically, I'm a fizzle. I am not blessed with a single pleasing feminine trait. Not a bosom, a hip, a curl or smile to make me desirable. My nose is bulbous, my very black eyes are bit too large for my face, I need to wear glasses and my cheeks have stayed a shiny, girlish pink. I have a proclivity to plumpness. (11)

Like most of the teenage youth who spend most of their time for their best appearance, as they concentrate only on their luxurious and gorgeous dresses, ornaments, and perfumes. But Shari does not have any interest. Even, she never blushed nor is overwhelmed with the word 'marriage'.

In an article Alka Saxena refer that "Mango-Coloured Fish": A Quest for Identity" Perspectives on Indian English Fiction rightly observes the novel as protagonist's searching for identity and pre-marriage dilemma. She observes:

Nambisan conveys to the readers the need to hold the reins of life is one's own hands. Marriage is no child play and so before taking the plunge one has to really prepare for it. The novel helps in building up courage and sensibility. Through the various characters Nambisan points out that living life of pretensions and fragmented personalities is no fun. (Saxena 169) 
Shari too wants to makes peace with her past. She finds in herself the inner strength to confront her own future and paves a way to the forth coming women generations in the Indian context, that need to learn to swim though not with the flow but can if need be swim across the current to retain their unflinching individuality..

\section{Conclusion}

In Mango-Coloured Fish (2000), the novelist projects the theme of "Sensibility" through the character of Shari, a young urban girl. Her life is controlled by a number of characters her domineering mother, a too perfect sister and a kind but a passive father. Her choices are shaped more by the social propriety than by her own will. She is thrown into a situation where she has inevitably agreed to marry a man of their choice. Being haunted by the ghosts of the past and painfully uncertain about her decision to marry, she escapes to her brother's house in Vrindaban a few weeks before the marriage more to a great deal of shock and utter dismay of her mother. She enters into the unpredictable lives of her brother and sister-in-law who are both doctors. She encounters with her memories of her past, her relationship with 'Naren', her blind friend and the shocking discovery of the truth about Uncle and Aunt 'Paru' whom she always considers to be her surrogate parents.

Kavery Nambisan portrays Shari, as a young woman who cannot hinder her desire of her first love and cannot deny her attraction towards Naren. Even though she believes that her parents will not accept her marriage, Shari's idea to make herself an autonomous being proves her potential. She is constantly suffers from dilemma - which way to go- what to do etc. Kavery Nambisan has shared her views on Shari in an interview as "Shari is an ordinary girl who is sensible enough to follow her heart."She firmly determined not to be like a fish in the glass bowl, which darts about in purposeless monotony because the space is restricted to its freedom. Earlier in Yash's house, Shari is impressed after seeing the sunlight reflecting at 
the glass and water on fish, and while arguing about its colour as mango-coloured. Though, the fish appears impressive in its mango coloured yet Shari did not want to restrict her own identity with that fish. She wants to trace out her self-identity and freedom in this world. Thus once again she started her return journey for Madras, she is not the confused, jittery and fickle-minded. It seems that Nambisan infuses the dreams of a young girl to portray Shari's status of predicament in her life from which she wants to find out the way out. 


\section{Works Cited:}

Anindita Chatterjee. “A Study of Manju Kapur's Difficult Daughters: Virmati, Ida and Shakuntala" Humanics Journal. Vol 8 No 1. 1-9. 2013. Print.

Chodorow Nancy. The Reproduction of Mothering: Psychoanalysis and the society of Gender (Berkeley: U of California p, 1978) Pp.81

Deshpande, Shashi. That long Silence (1988) Virago press ltd, 1988 pp.21, 153.

Doris Lessing: Conversations, ed. Earl G. Ingersoll (Princeton: Ontario Review Press, 1994. pp42, 198.

Doris Lessing: The Golden Notebook, ed. Tapan K. Ghosh. New Delhi: Prestige Books, 2006. P24.

Firestone (The Dialetic of Sex: The Case for Feminist Revolution, 1970) p-12

Guillaumin Colette Racism, sexism, power and ideology, published 1995 p-178

Jean, Maurice de Monetremy. A Writer is not a Professor (1990), Doris Lessing: Conversations, ed. Earl G. Ingersoll (Princeton: Ontario Review Press, 1994) Pp 42,198

ManeetaKahlon. Family Structure in Manju Kapur's Difficult Daughters and Home”. Dirwle. Vol. 7 No. 2. 1-11. 2011. Print.

Manu. Manusmruti; Women in Indian History: A Brief Survey, 5148.

Misra, Jaishree. Ancient Promises. Penguin books, 2000, pp21, Subsequent page references to the edition are parenthesized within the text.

Nambisan, Kavery. Mango-coloured fish. New Delhi: Penguin, 2000.

Saxena, Alka. "Mango-ColouredFish : A Quest for Identity". Perspectives on Indian English Fiction. DodiyaJayadipsingh K., ed. New Delhi : Creative Publications, 2002 p-169 
Sudha Shree, P. "Difficult Daughters: Travails in Self Identity". Indian Women Writing in English: New Perspectives. Ed. Sathupat, Prasanna Sree. New Delhi: Sarup\& Sons, 2005.Print.

Susie Tharu, K.Lalitha. Women Writing in India: 600 BC to the Present, 1991. P 247.

Y.S. Sunita Reddy -Fractured Memories": Small Remedies; A Feminist Perspective on the Novels of Shashi Deshpande, P. 123.

Web Sources:

www.en.wikipedia.org/wiki/Kavery Nambisan.

www. Chaudury, Prabhat. Sensitivity- KaveryNamisan.

www.countercurrent.org

www.Language in India .com 